
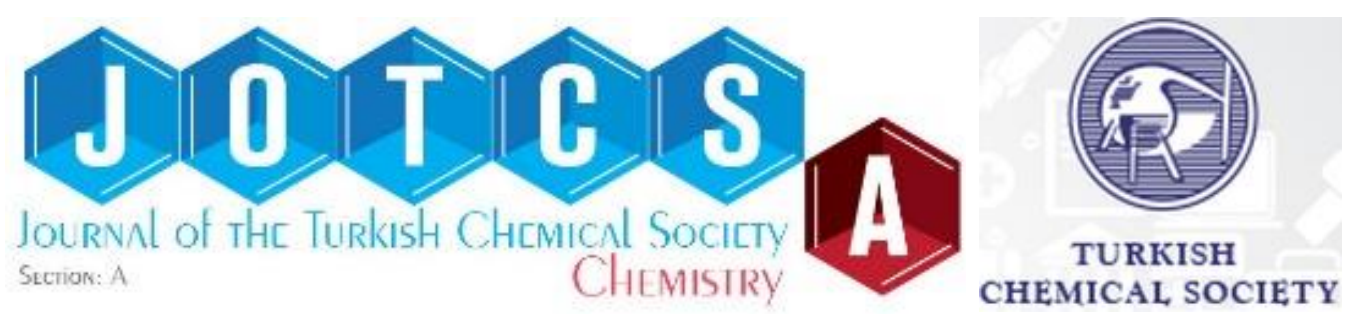

\title{
DNA Base Bioisosteres, Bis-benzoxazoles, Exert Anti-proliferative Effect on Human Prostate and Breast Cancer Cells
}

\author{
Furkan Ayaz ${ }^{*}$, Rusmeenee Kheeree ${ }^{1}$, Qadar Ahmed Isse ${ }^{1}$, Ronak Haj Ersan², Oztekin \\ Algul2* \\ ${ }^{1}$ Mersin University, Biotechnology Department, (33110), (Mersin), (Turkey) \\ 2Mersin University, Faculty of Pharmacy, Department of Pharmaceutical Chemistry, (33169),
} (Mersin), (Turkey)

Abstract: A series of symmetric bis-benzoxazole derivatives were synthesized using one-pot cyclization between 4-chloro substituted 2-aminophenol and suitable dicarboxylic acids. Synthesized compounds' anticancer activities were tested by using MTT assay on human prostate (DU145) and breast (MCF7) cancer cells. Screening results revealed that all compounds possessed a high level anti-cancer potential by significantly decreasing the cell proliferation in prostate and breast cancer cell lines. Our compounds exerted their anti-proliferative effects in a dose and time dependent manner. Our results suggest that they can be highly potent since they were biologically active even at low concentrations. Our study presents a series of new bis-benzoxazole based compounds with potential therapeutic effects against tumor cells. Therefore, characterization of new generation bisbenzoxazole derivatives will have a significant contribution on the development of new era anticancer drug candidates.

Keywords: Bis-benzoxazole, breast cancer, prostate cancer, anti-proliferative, anti-cancer, MTT.

Submitted: June 01, 2018. Accepted: September 18, 2018.

Cite this: Ayaz F, Kheeree R, Isse Q, Ersan R, Algul O. DNA Base Bioisosteres, Bis-benzoxazoles, Exert Anti-proliferative Effect on Human Prostate and Breast Cancer Cells. JOTCSA.

2018;5(3):1145-52.

DOI: https://dx.doi.org/10.18596/jotcsa.429504.

Corresponding authors. E-mails: furkanayaz@mersin.edu.tr, oztekinalgul@mersin.edu.tr.

\section{INTRODUCTION}

Cancer is one of the leading causes of death globally (1). Under normal conditions there is a cell renewal and replacement homeostasis in the tissues (2-5). After losing some of the cells, tissue would make up its loss by stimulating cell division and growth (2-6). In case of tumor cells, they circumvent the checkpoints of cell division which is enabled by multiple genetic alterations (7-15). This situation leads to uncontrolled cell growth and outnumbering of non-tumorous tissueresident cells which eventually causes the loss of function in these affected tissues (7-18).

As a treatment option, chemotherapy is widely used in the cancer patients (19-20).
Chemotherapeutics pause or slow down the pace of the abnormal cell division or cause the death of the rapidly dividing tumor cells (21, $22)$. These drugs have side effects that can exert its effect on healthy cells $(23,24)$. Severity of their side effects depends on the type and location of the cancer as well as the dosage used and patient's overall health condition (23-25). The most crucial side effect of chemotherapeutics is on the fast dividing blood cells of the patient (23-25). These drugs decrease the blood cell counts of the patients taking the treatment (23-25). This decrease of the blood cells compromises the immune system of the patients and makes them prone to infections (23-25). In order to avoid the common side effects such as fatigue, pain, diarrhea, hair loss, vomiting and nausea, new 
candidates of chemotherapeutics should be developed as alternatives $(26,27)$.

Newly developed benzoxazole compounds are important fragments in medicinal chemistry because of their wide range of biological activities, including anticancer activities (2830). They serve as topoisomerase-I inhibitors (31) and have antibacterial (32), antifungal (33), antimicrobial (34), and antiviral activities (35).

One of the main examples to benzoxazole based compounds is UK-1 (Bis-benzoxazole) (Figure 1) which has cytotoxic activity against a variety of tumorous cell types. In the quest of synthesizing more potent anticancer drugs, we designed and produced new bisbenzoxazole derivatives with high yields. In our study, we are presenting screening results for their anticancer activity against human breast cancer cell line (MCF-7) and prostate cancer cell line (DU145).<smiles>COC(=O)c1cccc2oc(-c3cccc4oc(-c5ccccc5O)nc34)nc12</smiles>

Figure 1. Molecular Structure of UK-1.

\section{MATERIALS AND METHODS}

\section{Chemistry}

General: Each reaction was followed by thin layer chromatography (TLC). UV (ultraviolet) light $(254 \mathrm{~nm})$ was used in the determination of stains on ready-made TLC plates (Kieselgel 60 F254, ready-to-use aluminum plate coated with $0.2 \mathrm{~mm}$ thickness). Flash column chromatography was performed with silica gel 60 (Merck, 63-200 $\mu \mathrm{m}$ particle size, 60-230 mesh). (Solvent of the flash column chromatography: n-hexane/ethyl acetate $80: 20$ )

${ }^{1} \mathrm{H}$ NMR and ${ }^{13} \mathrm{C}$ NMR spectra (Bruker 400 spectrometer) and Fourier transform infrared (FT-IR) spectra (Perkin Elmer Spectrum One FT-IR spectrometer) were used to elucidate the structures of the products.

Materials: All reagents and solvents for synthesis and analysis were of analytical and/or spectroscopic A grade (Sigma-Aldrich and ACROS) and used without further purification.

Synthesis: General Procedure for Synthesis of Bis-benzoxazole derivatives (Fig.2). Five $\mathrm{mmol}$ of the 4-chloro-2-aminophenol (1) and $2.5 \mathrm{mmol}$ of the corresponding dicarboxylic acid derivatives (2, and $\mathbf{3}$ ) are refluxed under a reflux condenser with a magnetic stirrer for a period of 13-15 hours after being dissolved in polyphosphoric acid (PPA) and heated in an oil-bath at $180^{\circ} \mathrm{C}$. The reactions were followed by TLC. After cooling, the reaction mixture was poured onto ice water and neutralized by mixing with $5 \mathrm{~N} \mathrm{NaOH}$ until being of slightly basic $\mathrm{pH}(8-9)$ to get the precipitate. The resulting precipitate was filtered off and washed with cold water. Then compounds purified by flash column chromatography finally crystallized with a suitable solvent. The resulting crystalline compounds were filtered and the vacuumed product was dried. 


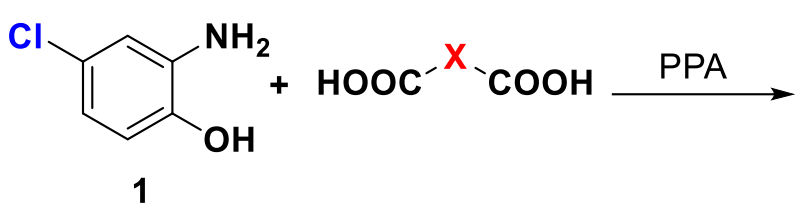<smiles>[X]c1nc2cc(Cl)ccc2o1</smiles>

$\begin{array}{cc}\mathbf{X}=-\mathrm{CH}_{2}-\mathrm{CH}_{2}-\mathrm{CH}_{2} & \mathbf{2} \\ -\mathrm{CH}_{2}-\mathrm{S}-\mathrm{CH}_{2} & \mathbf{3}\end{array}$ $\begin{aligned} X= & -\mathrm{CH}_{2}-\mathrm{CH}_{2}-\mathrm{CH}_{2} \\ & -\mathrm{CH}_{2}-\mathrm{S}-\mathrm{CH}_{2}-\end{aligned}$
RHE-231 RHE-241

Figure 2. General synthesis method of the compounds.

1,3-bis(5-chlorobenzo[d]oxazol-2-yl)propane RHE-231: The above procedure was followed with $\mathbf{1}$ and $\mathbf{2}$ to yield RHE-231 as a white crystalline solid (47\% yield). The crystallization solvent was ethanol-water (with the ratio of $1 / 1) . R_{f}$ (n-hexane:ethyl acetate $1: 1)=0,48 ; \mathrm{mp}=200^{\circ} \mathrm{C} ; \mathrm{IR}\left(\mathrm{KBr}, \mathrm{cm}^{-1}\right) \mathrm{V}_{\max }$ $3065,1567,1447,800,753,701 . ;{ }^{1} \mathrm{H}$ NMR $\left(400 \mathrm{MHz} \mathrm{CDCl}_{3}\right) \delta=7.52(\mathrm{~d}, J=1.99 \mathrm{~Hz}, 2 \mathrm{H}$, Ar-H), 7.32-7.29 (m, $1 \mathrm{H}, \mathrm{Ar}-\mathrm{H}), 7.20$ (dd, $\mathrm{J}=1.99 \mathrm{~Hz}, \mathrm{~J}=8.25 \mathrm{~Hz}, 3 \mathrm{H}, \operatorname{Ar}-\mathrm{H}), 3.05(\mathrm{t}$, $\left.\mathrm{J}=7.28 \mathrm{~Hz}, 4 \mathrm{H},-\mathrm{CH}_{2}\right), 2.43(\mathrm{p}, \mathrm{J}=2.48 \mathrm{~Hz}, 2 \mathrm{H}$, $\left.-\mathrm{CH}_{2}\right) \cdot{ }^{13} \mathrm{C} N M R\left(100 \mathrm{MHz}, \mathrm{CDCl}_{3}\right) \delta=167.3$, $149.4,142.4,129.8,125.0,119.7,111.0$, $27.8,23.4$.

1,3-bis((5-chlorobenzo[d]oxazol-2-

yl)methyl)sulfane RHE-241: The above procedure was followed with $\mathbf{1}$ and $\mathbf{3}$ to yield RHE-241 as a beige crystalline solid (45\% yield). The crystallization solvent was ethanolwater (with the ratio of $1 / 1) . \mathrm{R}_{\mathrm{f}}(\mathrm{n}-$ hexane: ethyl acetate $1: 1)=0,64 ; \mathrm{mp}=197$ ${ }^{\circ} \mathrm{C}$; FT-IR $\left(\mathrm{cm}^{-1}\right) \mathrm{V}_{\max } 2979,2923,1560$, $1447,1332,812$, 703. ; ${ }^{1} \mathrm{H}$ NMR (400 MHz, $\left.\mathrm{CDCl}_{3}\right) \delta=7.30-7.26(\mathrm{~m}, 2 \mathrm{H}, \mathrm{Ar}-\mathrm{H}), 7.21(\mathrm{dd}$, $\mathrm{J}=2.58 \mathrm{~Hz}, \mathrm{~J}=8.69 \mathrm{~Hz}, 2 \mathrm{H}, \mathrm{Ar}-\mathrm{H}), 6.98$ (td, $\mathrm{J}=2.58 \mathrm{~Hz}, \mathrm{~J}=8.69 \mathrm{~Hz}, 2 \mathrm{H}, \operatorname{Ar}-\mathrm{H}), 4.03(\mathrm{~s}, 4 \mathrm{H}$, $\left.-\mathrm{CH}_{2}\right) \cdot{ }^{13} \mathrm{C}$ NMR $\left(100 \mathrm{MHz}, \mathrm{CDCl}_{3}\right) \delta=164.6$, $161.2,158.8,147.4,142.0,141.9,113.1$, $112.8,110.9,110.8,106.6,106.4,28.5$.

\section{Biological studies}

In this study, breast cancer cell line MCF-7, prostate cancer cell line DU-145 and fibroblast cell line L929 were purchased from ATCC. The chemicals used in the study were bisbenzoxazole based RHE 231 and 241 coded compounds.

Reagents and Chemicals: RHE231 and RHE241; 2 mg of RHE231 and RHE241 were dissolved in $1000 \mu \mathrm{L}(1 \mathrm{~mL})$ of sterile dimethyl sulfoxide (DMSO).

Cell Culture: In this study the following cell lines were used: Fibroblast cell line; L929 from ATCC, breast cancer cell line; MCF7 from ATCC, and prostate cancer cell line; DU145 from ATCC. Cells were cultured in tissue culture plates with Roswell Park Memorial Institute media (RPMI 1640) media with \%10 fetal bovine serum, \%1 antibiotics $(100 \mu \mathrm{g} / \mathrm{mL}$ penicillin and $100 \mu \mathrm{g} / \mathrm{mL}$ streptomycin), and sodium pyruvate. Cultures were incubated at $37{ }^{\circ} \mathrm{C}$ in an atmosphere of $95 \%$ air and $5 \%$ $\mathrm{CO}_{2}$.

Cell Plating: Adherent cells from confluent cultures were detached, after they grew completely to reach the number of $10 \times 10^{6}$ cells/plate in $10 \mathrm{~mL}$ of RPMI-based complete culture medium as specified above. Cell counting was done by using Trypan Blue dye which stains the dead cells with dark blue color. The dye cannot penerate through living cells therefore we could differentiate between living and dead cells and have a reliable living cell number for the plating.

$100 \mu \mathrm{L}$ of $10 \times 10^{6}$ cells $/ \mathrm{mL}$ were seeded in individual wells of 96 well tissue culture treated plates and allowed to adhere to the surface by overnight incubation at $37^{\circ} \mathrm{C}$ and $5 \% \quad \mathrm{CO}_{2}$ before adding the reagents. $50 \mu \mathrm{g} / \mathrm{mL}, \quad 75 \mu \mathrm{g} / \mathrm{mL}$, and $100 \mu \mathrm{g} / \mathrm{mL}$ of reagent were added into appropriate wells. Afterwards the samples were incubated at 37 ${ }^{\circ} \mathrm{C}$ and $5 \% \quad \mathrm{CO}_{2}$ humidified incubator for different three time-points; 24h, 48h, and $72 \mathrm{~h}$.

Cytotoxicity Evaluations: MTT assay: Cell viability was evaluated by using MTT assay. This assay is based on the ability of viable cells to metabolize yellow tetrazolium salt MTT to purple formazan crystals by mitochondrial dehydrogenases and spectrophotometric measurement of the product at $570 \mathrm{~nm}$.

Briefly, cells were seeded at a density of $1 \times 10^{5}$ per well in 96-well plates; subsequently, after overnight incubation, they were treated with various concentrations ( $50 \mu \mathrm{g} / \mathrm{mL}, 75 \mu \mathrm{g} / \mathrm{mL}$, $100 \mu \mathrm{g} / \mathrm{mL}$ ) of RHE 231 \& RHE 241. Cells were put back to $37{ }^{\circ} \mathrm{C} 5 \% \mathrm{CO}_{2}$ incubator for 24 hours, 48 hours, and 72 hours of incubation. The untreated or DMSO treated well was considered as a negative control, and all samples were prepared in triplicates.

After $24 \mathrm{~h}, 48 \mathrm{~h}$, and $72 \mathrm{~h}$ of incubation, $10 \mu \mathrm{L}$ of MTT reagent was added into each well and samples were further incubated for $4 \mathrm{~h}$ at 37 
${ }^{\circ} \mathrm{C}, 5 \% \mathrm{CO}_{2}$. As a last step, $100 \mu \mathrm{L}$ of detergent reagent was added into each well. Cytotoxic effects were monitored by measuring the absorbance values of each well at $570 \mathrm{~nm}$.

Statistical Analysis: In order to determine the $\%$ cell viability average absorbance value of the reference blank sample was subtracted from each sample's average absorbance. The equation used for the calculations is given below and further plotting as well as statistical analysis were performed by GraphPad Prism Software version 5 . For each condition there were nine independent data points and unpaired two tail t-test was done to draw the statistical significance.

$$
\% \text { Viability }=\frac{\text { Sample absorbance }- \text { Reference absorbance }}{\text { Reference absorbance }}
$$

\section{RESULTS AND DISCUSSION}

Cell viability analysis indicated that both of the compounds, RHE231 and RHE241, were effective as anti-proliferative agents on DU145 prostate cancer cells, MCF7 breast cancer cells, and L929 fibroblast cells.
DU 145 24h

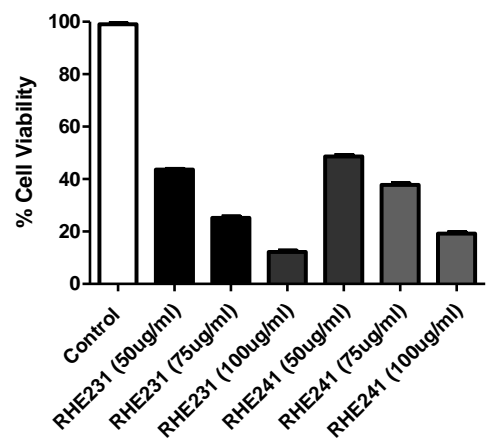

Figure 3: Dose-dependent effect of RHE231 and RHE241 on DU145 cell lines for 24h, $48 \mathrm{~h}$, and $72 \mathrm{~h}$ incubation, respectively.

MTT assay was done to asses cell viability. The $\mathrm{t}$ test was applied for statistical analysis, $\mathrm{p}<0.0001 \mathrm{~N}=9$.

The proliferation rate of prostate cancer cells (DU145) was negatively affected by RHE231 and RHE241, at all time points and at all concentrations compared to the untreated control wells which had $100 \%$ cell viability. There was a substantial decrease in RHE 231
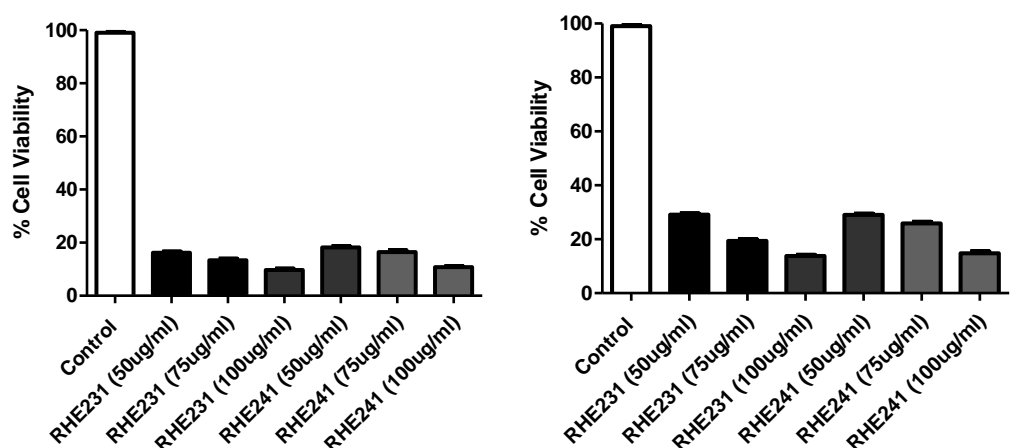

and 241 treated prostate cancer cells' percent viability compared to the untreated control wells. This difference was statistically significant. Dose dependent anti-proliferative effect of our reagents was more obvious at 24 hour time point but at later time points even the lowest dose $(50 \mu \mathrm{g} / \mathrm{mL})$ of both of the reagents was almost as effective as the highest one $(100 \mu \mathrm{g} / \mathrm{mL}$ ) (Figure 3 ).

MCF7 24h

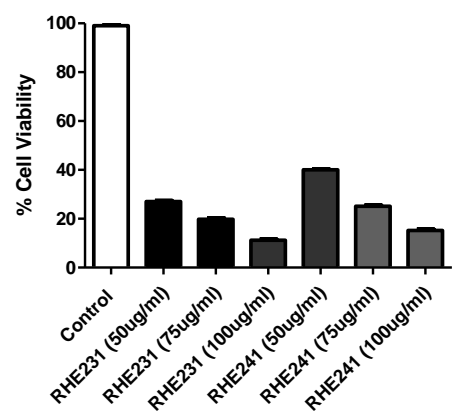

MCF7 48h

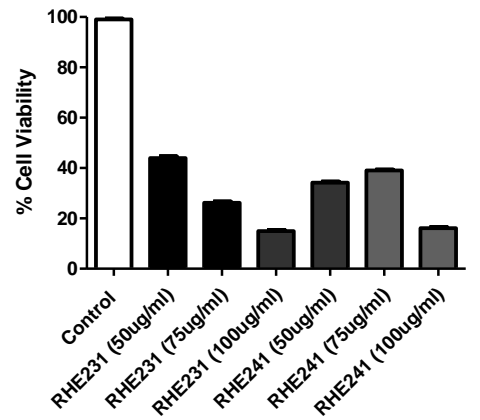

MCF7 72h

Figure 4: Dose-dependent effect of chemicals, including RHE 231 and RHE 241 on MFC7 cell lines for $24 \mathrm{~h}, 48 \mathrm{~h}$, and $72 \mathrm{~h}$ incubation, respectively.

MTT assay was performed to assess cell viability. The t test was applied for statistical analysis, $\mathrm{p}<0.0001 \mathrm{~N}=9$.
We obtained similar results when we tested the effect of RHE 231 and RHE 241 on the 
breast cancer cells (MCF7) as those of the prostate cancer cells (DU145). When we took the untreated cells as reference point there was a substantial and significant decrease in the level of cell proliferation in RHE 231 and RHE 241 treated cells. We observed a dose dependent effect since at higher concentrations of used chemicals there was more substantial decrease in the percent cell viability compared to the wells treated with the
L929 48h lower concentrations of the chemicals (Figure 4). RHE 231 and 241 exerted their effect in a time dependent fashion on DU145 cells whereas on MCF7 cells, the anti-proliferative effect was fully shown even at the 24 hour time point since at 48 and 72 hour time points the observed anti-proliferative effect was similar to that of 24 hour time point (Figures 3 and 4 ).
L929 24h

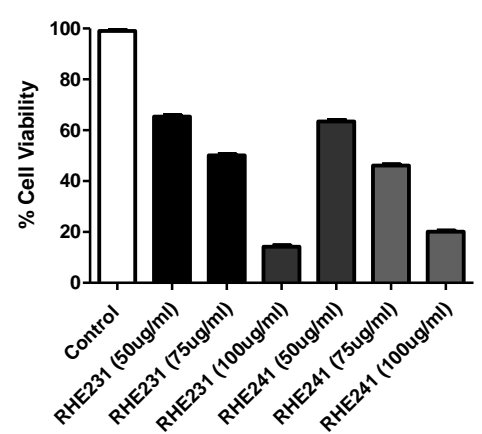

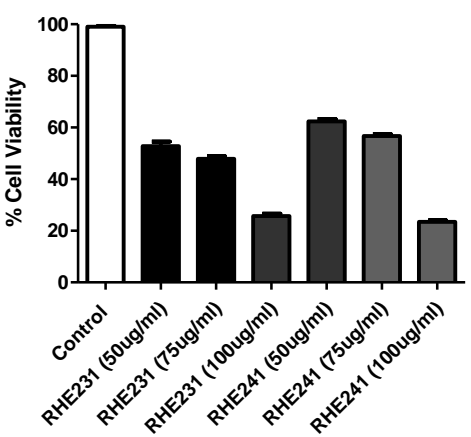

L929 72h

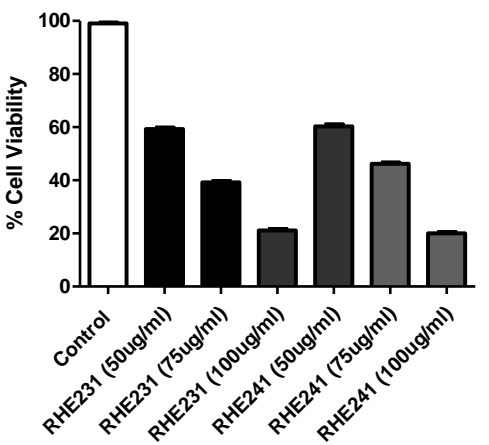

Figure 5: Dose-dependent effect of chemicals, including RHE 231 and RHE 241 on L929 cell lines for $24 \mathrm{~h}, 48 \mathrm{~h}$, and $72 \mathrm{~h}$ incubation, respectively.

MTT assay was performed to assess cell viability. The $t$ test was applied for statistical analysis, $\mathrm{p}<0.0001 \mathrm{~N}=9$.

In order to test the possible cytotoxic side effects of our compounds we tested their antiproliferative effect on the mouse fibroblast cells L929. Our chemicals exerted antiproliferative activity on fibroblast cells in a time and dose dependent manner as well (Figure 5). There was a significant decrease in the cell viability of treated fibroblasts compared to the untreated control wells. When we compared the results to those of breast cancer (MCF7) and prostate cancer (DU145) cells, fibroblasts (L929) had higher cell viability at all time points especially at lower dosages (Figure 5). This implies that our reagents would show less cytotoxic effect on normal cell types compared to the breast and prostate cancer cells. Especially, lower doses of RHE 231 and 241 can be effectively used against breast and prostate cancer since event at $50 \mu \mathrm{g} / \mathrm{mL}$ concentration our reagents had highly potent anti-proliferative activity on these cancer cells whereas they did not cause as substantial of a decrease in the viability of the fibroblasts (Figures 3-5). In the presence of our chemicals, fibroblasts had higher cell viability, compared to those of prostate and breast cancer cells.

\section{DISCUSSION}

Chemotherapy stands as the most viable option in the current medicinal approaches against the cancer (19-22). These drugs target the fast-dividing cells in the body (21, 22 ). Tumor cells fall into this category due to their higher proliferation rate compared to the normal cells (7-15, 19-22). One major problem with this treatment is the side effects associated with it $(23,24)$. Normal cell types with high proliferation and cell division rates such as endothelial cells of the intestines, hair and blood cells are severely affected by the treatment (23-25). The severity of the side effects depends on the patient's genetic background as well as the type of the cancer and chemotherapeutics used (23-25).

In order to circumvent these side effects, there is an urgent need of design and synthesis of new drug candidates and of their testing on the cancer cells $(26,27)$. In our study, we focused on two cancer types that have one of the highest incidence rates among men (prostate cancer) and women (breast cancer). Anti-proliferative activity of some other bis-benzoxazole derivatives have been shown by previous studies $(36,37)$. In our study we designed two new bis-benzoxazole derivatives and further examined their effect on the prostate (DU145) and breast (MCF7) cancer cells.

Our study supports that RHE231 and RHE241 have anti-proliferative effect on breast cancer and prostate cancer cells in a time and dose dependent fashion. Both of the reagents caused a significant decrease in cell viability compared to the untreated control wells. MCF7 cells were affected more by the treatment 
compared to the DU 145 cells. But at later time points 48 and 72 hours, our reagents showed their strong anti-proliferative effect on the prostate cancer cells as well.

In order to test the cytotoxic activity of our reagents on normal cells we used fibroblast cells (L929). Our compounds caused a significant decrease in the cell viability of fibroblasts compared to the untreated cells, but this decrease was not as substantial as those of treated breast and prostate cancer cells at all time points. Especially the lowest concentrations of the chemicals would be effective chemotherapeutics since while they would have high potency against breast and prostate cancer cells during the treatment; they would not affect the normal cell types like fibroblasts of the tissues as substantially. This would enable an efficient anti-proliferative effect on the tumor cells while sparing majority of the normal cells in the tissue so that those cells can heal the tissue aftermath of the treatment.

\section{CONCLUSION}

Our results support anti-proliferative, therefore anti-cancer, activities of bisbenzoxazole derivatives RHE 231 and RHE 241. In our future studies we will be focusing more on the molecular mechanism of our compounds action on the cancer cells as well as normal cell types. Possible hit points include oncogenes such as p53, Ras and Notch pathways.

\section{ACKNOWLEDGMENTS}

This study was supported by 2017-2-AP-42506 BAP Project of Mersin University and The Scientific and Technological Research Council of Turkey (TUBITAK, Grant Number: 115S190). Our group greatly appreciates the material support of Prof.Dr. Juan Anguita from CICBiogune.

\section{REFERENCES}

1. Fitzmaurice $C$, Dicker D, Pain A, Hamavid $H$, Moradi-Lakeh M, MacIntyre $M$, et al. Global Burden of Disease Cancer Collaboration The Global Burden of Cancer 2013. JAMA Oncol. 2015;2015(1):505-27.

2. Biteau B, Hochmuth $C E$, Jasper $H$. Maintaining Tissue Homeostasis: Dynamic Control of Somatic Stem Cell Activity. Cell Stem Cell. 2011 Nov;9(5):402-11.

3. Alvarado C, Fider NA, Wearing $\mathrm{HJ}$, Komarova NL. Optimizing homeostatic cell renewal in hierarchical tissues. Traulsen $A$, editor. PLOS Computational Biology. 2018 Feb $15 ; 14(2)$ :e1005967.

4. Pellettieri J, Alvarado AS. Cell Turnover and Adult Tissue Homeostasis: From Humans to Planarians. Annual Review of Genetics. 2007 Dec;41(1):83-105.

5. Antonello ZA, Reiff T, Dominguez M. Mesenchymal to epithelial transition during tissue homeostasis and regeneration: Patching up the Drosophila midgut epithelium. Fly. 2015 Jul 3;9(3):132-7.

6. Hunt T, Nasmyth K, Novak B. The cell cycle. Philosophical Transactions of the Royal Society B: Biological Sciences. 2011 Dec 27;366(1584):3494-7.

7. Williams GH, Stoeber K. Cell cycle markers in clinical oncology. Current Opinion in Cell Biology. 2007 Dec;19(6):672-9.

8. Bower JJ, Karaca GF, Zhou Y, Simpson DA, Cordeiro-Stone M, Kaufmann WK.

Topoisomerase IIa maintains genomic stability through decatenation G2 checkpoint signaling. Oncogene. 2010 Aug;29(34):4787-99.

9. Hartwell L, Kastan M. Cell cycle control and cancer. Science. 1994 Dec

$16 ; 266(5192): 1821-8$.

10. Classon M, Harlow E. The retinoblastoma tumour suppressor in development and cancer. Nature Reviews Cancer. 2002 Dec;2(12):910-7.

11. Xu B, Kim S -t., Kastan MB. Involvement of Brca1 in S-Phase and G2-Phase Checkpoints after Ionizing Irradiation. Molecular and Cellular Biology. 2001 May $15 ; 21(10): 3445-50$.

12. Wang R-H, Yu H, Deng C-X. A requirement for breast-cancer-associated gene 1 (BRCA1) in the spindle checkpoint. Proceedings of the National Academy of Sciences. 2004 Dec 7;101(49):17108-13.

13. Santarpia $L$, Iwamoto $T$, Di Leo $A$, Hayashi N, Bottai G, Stampfer M, et al. DNA Repair Gene Patterns as Prognostic and Predictive Factors in Molecular Breast Cancer Subtypes. The Oncologist. 2013 Oct $1 ; 18(10): 1063-73$.

14. Sorlie $T$, Perou CM, Tibshirani R, Aas $T$, Geisler S, Johnsen $\mathrm{H}$, et al. Gene expression patterns of breast carcinomas distinguish tumor subclasses with clinical implications. Proceedings of the National Academy of Sciences. 2001 Sep 11;98(19):10869-74. 
15. Nakagawa $T$, Hayashita $Y$, Maeno $K$, Masuda A, Sugito N, Osada $H$, et al. Identification of Decatenation $\mathrm{G} 2$ Checkpoint Impairment Independently of DNA Damage G 2 Checkpoint in Human Lung Cancer Cell Lines. Cancer Research. 2004 Jul $15 ; 64(14): 4826-32$.

16. Hinck L, Näthke I. Changes in cell and tissue organization in cancer of the breast and colon. Current Opinion in Cell Biology. 2014 Feb;26:87-95.

17. Cho EH, Wendel M, Luttgen M, Yoshioka C, Marrinucci D, Lazar D, et al. Characterization of circulating tumor cell aggregates identified in patients with epithelial tumors. Physical Biology. 2012 Feb $1 ; 9(1): 016001$.

18. De Smedt L, Palmans S, Sagaert X. Tumour budding in colorectal cancer: what do we know and what can we do? Virchows Archiv. 2016 Apr;468(4):397-408.

19. Gustavsson B, Carlsson G, Machover D, Petrelli N, Roth A, Schmoll H-J, et al. A Review of the Evolution of Systemic Chemotherapy in the Management of Colorectal Cancer. Clinical Colorectal Cancer. 2015 Mar;14(1):1-10.

20. Huang $C-Y$, Ju D-T, Chang C-F, Muralidhar Reddy $P$, Velmurugan BK. A review on the effects of current chemotherapy drugs and natural agents in treating non-small cell lung cancer. BioMedicine. 2017 Dec;7(4):23.

21. Harrison's principles of internal medicine [Internet]. NCBI; [cited 2018 Jun 1]. Available from:

https://www.ncbi.nlm.nih.gov/nlmcatalog/10 1643730

22. Andreae S, editor. Lexikon der Krankheiten und Untersuchungen. 2., überarbeitete und erw. Aufl. Stuttgart; New York: G. Thieme; 2008. 1468 p.

23. Pearce A, Haas M, Viney R, Pearson S-A, Haywood $P$, Brown $C$, et al. Incidence and severity of self-reported chemotherapy side effects in routine care: A prospective cohort study. Ganti AK, editor. PLOS ONE. 2017 Oct $10 ; 12(10): \mathrm{e} 0184360$.

24. Ihbe-Heffinger $A$, Ehlken $B$, Bernard $R$, Berger K, Peschel C, Eichler H-G, et al. The impact of delayed chemotherapy-induced nausea and vomiting on patients, health resource utilization and costs in German cancer centers. Annals of Oncology. 2004 Mar;15(3):526-36.

25. Khoshbin AR, Mohamadabadi $F$, Vafaeian F, Babania A, Akbarian S, Khandozi R, et al. The effect of radiotherapy and chemotherapy on osmotic fragility of red blood cells and plasma levels of malondialdehyde in patients with breast cancer. Reports of Practical Oncology \& Radiotherapy. 2015 Jul;20(4):305-8.

26. Hu Q, Sun W, Wang C, Gu Z. Recent advances of cocktail chemotherapy by combination drug delivery systems. Advanced Drug Delivery Reviews. 2016 Mar;98:19-34.

27. Hoelder S, Clarke PA, Workman P. Discovery of small molecule cancer drugs: Successes, challenges and opportunities. Molecular Oncology. 2012 Apr;6(2):155-76.

28. Ueki M, Ueno K, Miyadoh S, Abe K, Shibata K, Taniguchi M, et al. UK-1, a novel cytotoxic metabolite from Streptomyces sp. 517-02. I. Taxonomy, fermentation, isolation, physico-chemical and biological properties. The Journal of Antibiotics. 1993;46(7):108994.

29. Cheng CC, Dong Q, Liu DF, Luo YL, Liu $L F$, Chen AY, et al. Design of antineoplastic agents on the basis of the 2-

phenylnaphthalene-type structural pattern. 2 . Synthesis and biological activity studies of benzo[b]naphtho[2,3-d]furan-6,11-dione derivatives. Journal of Medicinal Chemistry. 1993 Dec;36(25):4108-12.

30. Kamal A, Srinivasa Reddy T, Polepalli S, Paidakula S, Srinivasulu V, Ganga Reddy V, et al. Synthesis and biological evaluation of 4-aza-2,3-dihydropyridophenanthrolines as tubulin polymerization inhibitors. Bioorganic \& Medicinal Chemistry Letters. 2014 Aug;24(15):3356-60.

31. Kim JS, Sun Q, Gatto B, Yu C, Liu A, Liu $L F$, et al. Structure-activity relationships of benzimidazoles and related heterocycles as topoisomerase I poisons. Bioorganic \& Medicinal Chemistry. 1996 Apr;4(4):621-30.

32. Sun L-Q, Chen J, Bruce M, Deskus JA, Epperson JR, Takaki K, et al. Synthesis and structure-activity relationship of novel benzoxazole derivatives as melatonin receptor agonists. Bioorganic \& Medicinal Chemistry Letters. 2004 Jul;14(14):3799802.

33. Ertan T, Yildiz I, Tekiner-Gulbas B, Bolelli K, Temiz-Arpaci O, Ozkan S, et al. Synthesis, biological evaluation and 2D-QSAR analysis of 
benzoxazoles as antimicrobial agents. European Journal of Medicinal Chemistry. 2009 Feb;44(2):501-10.

34. Alper-Hayta S, Arisoy M, Temiz-Arpaci Ö, Yildiz I, Aki E, Özkan S, et al. Synthesis, antimicrobial activity, pharmacophore analysis of some new 2-

(substitutedphenyl/benzyl)-5-[(2benzofuryl)carboxamido]benzoxazoles. European Journal of Medicinal Chemistry. 2008 Nov;43(11):2568-78.

35. Sun A, Prussia A, Zhan W, Murray EE, Doyle J, Cheng L-T, et al. Nonpeptide
Inhibitors of Measles Virus Entry. Journal of Medicinal Chemistry. 2006 Aug;49(17):508092.

36. Padmavathi V, Venkatesh BC, Muralikrishna A, Padmaja A. Synthesis and Antioxidant Activity of a New Class of Bis and Tris Heterocycles. Archiv der Pharmazie. 2012 Sep;345(9):745-52.

37. Ravez S, Castillo-Aguilera O, Depreux P, Goossens L. Quinazoline derivatives as anticancer drugs: a patent review (2011 present). Expert Opinion on Therapeutic Patents. 2015 Jul 3;25(7):789-804. 